\title{
The Strategic Entrepreneurship Impact of Performance on Indonesian E-Commerce
}

\author{
Rian Ristyanti ${ }^{1}$ and Anton Wachidin Widjaja ${ }^{2}$ \\ Universitas Indonesia, Indonesia ${ }^{1,2}$ \\ rianristyanti@gmail.com ${ }^{1}$, antonwachidinwidjaja@ hotmail.co²
}

\begin{abstract}
This study aims to empirically examine the effect of strategic entrepreneurship in relation to dynamic capabilities and innovation in the achievement of performance in the E-Commerce sector. The results of the study have been proved that strategic entrepreneurship in relation to dynamic capabilities and innovation can impact performance. This research includes survey research using Structural Equation Modelling (SEM) analysis with Partial Least Square (PLS) method to test the research hypothesis.
\end{abstract}

Keywords: Strategic Entrepreneurship; Dynamic Capabilities; Innovation; Ecommerce Performance.

\section{Introduction}

E-commerce is integral parts of today's modern society. The rapid development of technology allows online shopping to become faster and easier. The [1] revealed that Indonesia has one of the fastest growing online markets in Asia. In 2020, Indonesian ecommerce projections at $\$ 130$ billion (number 3 after China and India). Google projected by 2025, Indonesia will dominate 52 percent of all e-commerce activity in Southeast Asia [2]. With a population of over 250 million and rapidly growing internet adoption, Indonesia could offer a booming market for online shopping [3]. Indonesian Ecommerce Association projected to triple between 2014 and 2016 to reach \$20.8 billion (MENA Report, 2016). With those huge business prospect, Indonesian government altered regulations to allow 100-percent foreign ownership for investments in e-commerce company in the country [3]. To keep in mind, e-commerce companies in Indonesia also have high intensity in terms of competitions in dynamic environment.

Dynamic environment reflect uncertainty in the business environment [4]. According to [5], the survival of e-commerce is becoming increasingly uncertain in dynamic environments. This happened because the digital revolution had changed the ways business fundamentals became digital [6]. Changes in business concepts will make every e-commerce enter a tight competition that causes the product life cycle and business model to be shorter. So that requires e-commerce to quickly adapt to the dynamics of the business environment such as trying new strategic approaches, finding new opportunities [7]and revising routines that form the foundation of a new resource base [8] and compete in environmental turbulence [9].

In environmental turbulence, external pressure will damage the value of company resources resulting in short-term competitive advantage [10]. Strategic entrepreneurship is needed for companies to adapt to the dynamics of the environment. The concept of strategic 
entrepreneurship is simultaneous integration between two behaviors, namely opportunity seeking behavior (ie entrepreneurship) and competitive advantage creation behavior (i.e. strategic management) [11] In an effort to create prosperity and sustainable competitive advantage, e-commerce needs to balance these two behaviors. Implementation of strategic entrepreneurship occurs when companies combine the search for opportunities with a strategic perspective [11]. So that company activities become more balanced and not only focus on one side. In this study, strategic entrepreneurship is viewed from the standpoint of environmental dynamics in changing business in the e-commerce sector.

Dynamic capabilities are important for companies to support strategic entrepreneurship in the face of changing business environments. Companies that have dynamic capabilities will be better in strategic entrepreneurship [12]. Dynamic capabilities have seen as a means of changing the company's resource base and modifying a company's capabilities into new capabilities that are suitable for competing in changing business environments [13] that depend on company knowledge [14] through four dimensions, namely sensing, learning, integrating and coordinating [15].

In addition, value creation for customers in strategic entrepreneurship is creating new products and services through innovation [6]. [5] argue that the key dimension of strategic entrepreneurship is the emphasis on innovation. The context of innovation in this research is innovation in e-commerce. Innovation can also represent the company's resource base that will distinguish it from its competitors [16], [17]. Innovation in e-commerce will have a significant impact on enhancing strategic entrepreneurial capabilities through business models and core components owned by e-commerce [18]

The interesting research context, because dynamic environment in Indonesian ecommerce. Changes in the dynamic environment demand the founders or entrepreneurs of Indonesian e-commerce to adopt strategic entrepreneurship to survive on an ongoing basis. Finally, strategic entrepreneurship on Indonesian e-commerce is still regarded as a new research topic and the research that has been done so far are largely [11], [19], [20]. A wellimplemented strategic entrepreneurship should make e-commerce experience performance improvements and success that can ensure their survival. This problem becomes interesting to investigate about how strategic entrepreneurship implementation in e-commerce is.

\section{Literature Review}

\subsection{Research Model}

In this study, the research model can be seen in Figure 2.1 below which designed to deep investigate the strategic entrepreneurship implementation in Indonesian e-commerce. This model relates three concepts which are strategic entrepreneurship, dynamic capabilities and innovation. Finally, it examines the impact on performance of e-commerce. 


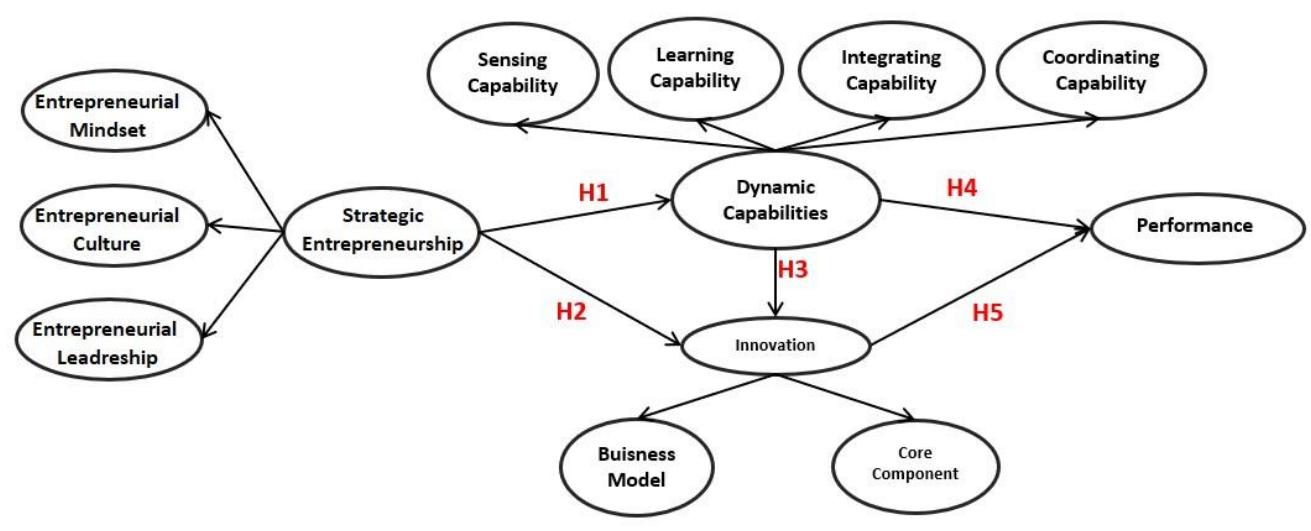

Fig. 1. Research model

\subsection{Hypothesis Development}

According to research model in the section above, the formulated hypothesis needs to be tested. The formulation of the hypothesis is divided into five sections. First one is about the relationship of strategic entrepreneurship with dynamic capabilities. Second hypothesis are the relationship of strategic entrepreneurship and innovation. Third is talking about relationship of dynamic capabilities and innovation. Next, the hypothesis analyses dynamic capabilities and performance. Finally, the hypothesis relates among innovation and performance.

\subsubsection{Research Model}

Companies that are successful passed by the dynamic environment depends on dynamic capabilities in forming strategic entrepreneurial activities [12]. Strategic entrepreneurial activities especially in seizing opportunities can be stimulated by dynamic [21], sensing ability, learning ability, integrating ability and coordinating ability [15] Based on these four capabilities: sensing, learning, integrating, and coordinating [15], companies will be ready to carry out strategic entrepreneurial activities. Therefore, first hypotheses which need to be tested can be formulated as follows:

Hypothesis 1: In the strategic entrepreneurship in e-commerce, strategic entrepreneurship has a positive effect on dynamic capabilities.

\subsubsection{Strategic Entrepreneurship and Innovation}

The main motivation behind strategic entrepreneurship stated by [11] that the firm is hard to identify and to explore new opportunities while simultaneously maintain and exploit competitive advantages. The presence of opportunities is very important as it can support strategic entrepreneurship to the process of performance. Then, [19] added emphasis that new opportunities can be utilized to make innovations as the foundation of future competitive advantages.

Innovation analysed by [18] provides a better understanding of how innovation will affect the capabilities of E-commerce's stakeholders to grab the opportunities in certain technological components. Innovation take a much broader view of the emerging technology and market opportunities to rethink the value and opportunity. The opportunity is congruent with current capabilities. Market niches should be identified with the unique features of these 
innovations which also supported by strategic entrepreneurship. To keep in mind, innovation are the cornerstones of the wealth creation [22].

Thus, several hypotheses which need to be tested can be formulated as follows:

Hypothesis 2: In the strategic entrepreneurship in e-commerce, strategic entrepreneurship has a positive effect on innovation.).

\subsubsection{Dynamic Capabilities and Innovation}

The time when companies are faced with dynamic environmental (resulting in uncertainty, rapidly changing and complex environmental conditions) often as supported factor in many organizations to innovate [23]. On the one hand, dynamic capabilities is the ability to integrate, build and reconfigure internal and external competencies to cope with rapid environmental change [24]. Meanwhile, innovation will have significant impact on the capabilities and assets of existing stakeholders and result in many novel change management issues [18]. Innovation is characterized by enhancement of quality, efficiency, accuracy and flexibility while dynamic capability enhances a company's ability to adapt to environmental change. So, innovation in rapidly changing environments has an impact on the formation of dynamic capabilities (Jiao et al., 2011; Lawson and Samson, 2001). Dynamic capabilities positively impact e-commerce innovation, both product and process innovation (Parthasarathy et al., 2011).

So, hypotheses which need to be tested can be formulated as follows:

Hypothesis 3: In the strategic entrepreneurship in e-commerce, dynamic capabilities have a positive effect on innovation.

\subsubsection{Dynamic Capabilities and Performance}

Companies that have dynamic capabilities can sense new market trends, capture opportunities and recognize threats (sensing ability), understand customer needs, and perform tasks effectively and efficiently by implementing new knowledge (learning ability) before competitors [15]. In addition, it can combine knowledge (integrating ability) (Pavlou \& el Sawy, 2011), assets and resources [9] to develop new capabilities then coordinating the resource base to differentiate their products and services from competitors [15]. So. the company can pursue and achieve predetermined targets that will have an impact on performance. Therefore, hypotheses which need to be tested can be formulated as follows:

Hypothesis 4: In the strategic entrepreneurship implementation in e-commerce, dynamic capabilities have a positive effect on performance.

\subsubsection{Innovation and Performance}

In the globalization and digitalization era, innovation can be said to be a tool for corporate adaptation to its environment [25] by creating products and services to customers [26]. The company acts in the dynamics environment through innovation to maintain competitive advantage [27]. [28] told companies were currently encouraged to compete in order to create competitive advantage through innovation. Innovation helps e-commerce in designing to create product/service specifications and applied business models which combined with technology infrastructure. Innovation in the context of e-commerce has two criteria according to [18], namely business models and core components including technology infrastructure. Technology infrastructure facilitates ecommerce in making business models that are suitable and needed by e-commerce. Thus, innovation is needed to maintain competitive advantage [29]. Thus, the hypothesis which need to be tested can be formulated as follows: 
Hypothesis 5: In the strategic entrepreneurship implementation in e-commerce, ecommerce has a positive effect on performance.

\subsection{Measurement}

This model relates five concepts. First one, the concept of strategic entrepreneurship which are entrepreneurial culture, entrepreneurial leadership and entrepreneurial mindset. Each variable has several indicators which can use for measurement.

The elements of strategic entrepreneurship will deserve as the input at different level for further process to next variables dynamic capabilities (sensing, learning, integrating and coordinating), innovation (model business and core components), then will impact performance as the output. Finally, the comprehensive research model can be seen in Figure 2.3. on below.

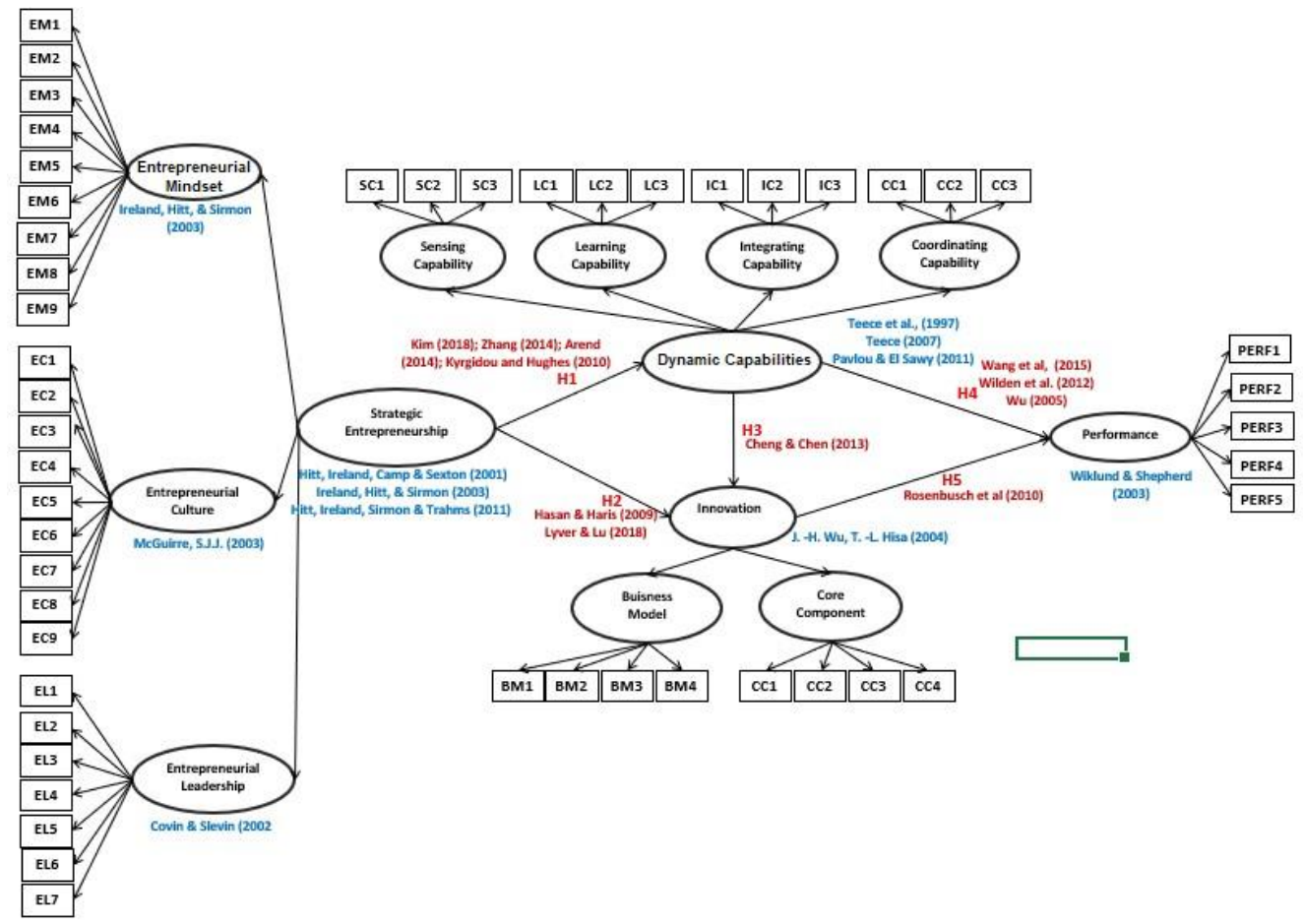

Fig. 2. Measurement

\subsection{Operationalized Variables}

Several prior studies have conducted the measurements of operationalized variables. So the questionnaire will be adopted from it in accordance with the context of e-commerce in Indonesia. All of the items were evaluated by a six-point Likert scale where 1 represents "strongly disagree" and 6 represents "strongly agree".

\subsubsection{Strategic Entrepreneurship Construct}

According to Ireland, [30] conducted the model of strategic entrepreneurship to several dimensions: (1) Entrepreneurial Mindset; (2) Entrepreneurial Culture and (3) Entrepreneurial Leadership. 
Entrepreneurial mindset refers to Ireland, Hitt \& Simon (2003) divided into: (1) Recognize Opportunity, (2) Entrepreneurial Awareness, (3) Real Choice Logic, and (4) Entrepreneurial Framework. The questioner used in this research adapted and validated from [31].

Entrepreneurial culture refers to [11] divided into: (1) Openness communication, (2) Proactive innovation, (3) Cooperation, and (4) Risk taking. The questioner used in this research adapted and validated from [32].

Entrepreneurial Leadership are divided by: (1) Strategy, (2) Communication, (3) Motivation, and (4) Personal and/or organization. The questioner used in this research adapted and validated from [11].

Table 1. Operationalization for Strategic Entrepreneurship

\begin{tabular}{|c|c|c|c|}
\hline Variables & Dimensions & Indicators & Source \\
\hline \multirow{3}{*}{$\begin{array}{c}\text { STRATEGIC } \\
\text { ENTREPRENEURSHIP }\end{array}$} & Entrepreneurial Mindset & $\begin{array}{l}1 \text { Recognize Opportunity } \\
2 \text { Entrepreneurial Awareness } \\
3 \text { Real Choice Logic } \\
4 \text { Entrepreneurial Framework }\end{array}$ & $\begin{array}{l}\text { Ireland, } \\
\text { Hitt, \& } \\
\text { Sirmon } \\
\text { (2003); Li et } \\
\text { al., (2016) }\end{array}$ \\
\hline & Entrepreneurial Culture & $\begin{array}{l}1 \text { Openness communication } \\
2 \text { Proactive innovation in products, processes and } \\
3 \text { Cooperation } \\
4 \text { Risk taking }\end{array}$ & $\begin{array}{l}\text { Ireland, } \\
\text { Hitt, \& } \\
\text { Sirmon } \\
\text { (2003); } \\
\text { McGuirre, } \\
\text { S.J.J. (2003) }\end{array}$ \\
\hline & Entrepreneurial Leadership & $\begin{array}{l}1 \text { Entrepreneurial Skill } \\
2 \text { New Innovation } \\
3 \text { Available Opportunities } \\
4 \text { Evaluates and Review Market } \\
5 \text { Manage Resource Effectively }\end{array}$ & $\begin{array}{l}\text { Ireland, } \\
\text { Hitt, \& } \\
\text { Sirmon } \\
(2003)\end{array}$ \\
\hline
\end{tabular}

\subsubsection{Dynamic Capabilities Construct}

The dynamic capabilities framework is the company' ability to integrate, build and reconfigure

include internal and external competences to compete in rapid environment change [24], the dimension namely sensing, sizing, and reconfiguring. Sensing is firm' ability to identify the opportunities in uncertain environment which affected the firm' performance [33]. Once new opportunities even technology or market are sensed, the opportunities must be pushed into new product, processes or service. This phrase requires investment in development and commercialization called seizing [33]. Capability can be developed on the internal firm through the transformation of existing capabilities then transformed into new capabilities [33]. It capabilities must be integrated into the existing configuration [33], [34] In this research, the questioner used to adapt and validated from Kyrgidou, 2010.

Table 2. Operationalization for Dynamic Capabilities 


\begin{tabular}{|c|c|c|c|}
\hline Variables & Dimensions & Indicators & Source \\
\hline \multirow{3}{*}{$\begin{array}{l}\text { DYNAMIC } \\
\text { CAPABILITY }\end{array}$} & Sensing & $\begin{array}{l}1 \text { Scanning external conditions in terms of creating new products } \\
2 \text { Encourage learning and discussion processes of creating new }\end{array}$ & \multirow{3}{*}{$\begin{array}{l}\text { Teece et al., } \\
\text { (2007); } \\
\text { Kyrgidou, } \\
(2010)\end{array}$} \\
\hline & Seizing & $\begin{array}{l}1 \text { Transforming information that has become new knowledge } \\
2 \text { Assimilate internal knowledge through knowledge sharing }\end{array}$ & \\
\hline & Reconfiguring & $\begin{array}{l}1 \text { Reconfigure resources to build productive and effective new assets } \\
2 \text { Combining resources and assets owned to achieve the target }\end{array}$ & \\
\hline
\end{tabular}

\subsubsection{Innovation Construct}

An innovation, such as a system or a product, can be seen as a historical change in the way a "thing is done" and as "creative destruction" [27]. Thus, following Afuah and

[35] which has been tested of the study by [18], to examine ECommerce innovation includes three dimensions: (1) Business models, and (2) Core components. The questioner used in this research adapted and validated from [18].

Table 3. Operationalization for innovation

\begin{tabular}{|c|c|c|c|}
\hline Variables & Dimensions & Indicators & Source \\
\hline \multirow{2}{*}{$\begin{array}{l}\text { E-COMMERCE } \\
\text { INNOVATION }\end{array}$} & Business Model & $\begin{array}{ll}1 & \text { Value Proposition } \\
2 & \text { Market Segment } \\
3 & \text { Profit potential } \\
4 & \text { Value network } \\
\end{array}$ & \multirow{2}{*}{$\begin{array}{l}\text { J. -H. Wu, T. } \\
\text { L. Hisa } \\
\text { (2004) }\end{array}$} \\
\hline & Core Components & $\begin{array}{ll}1 & \text { Technological Infrastructure } \\
2 & \text { Content } \\
3 & \text { Services }\end{array}$ & \\
\hline
\end{tabular}

\subsubsection{Performance Construct}

[36] has defined wealth creation as perception of owners or decision makers regarding the growth of company performance. In this research, the questioner used to adapt and validated from [37].

Table 4. Operationalization for Performance

\begin{tabular}{|c|l|l|c|}
\hline Variables & Dimensions & \multicolumn{1}{c|}{ Indicators } & Source \\
\hline & & 1 Profits increase & Wiklund \& \\
WEALTH CREATION & & 2 Product/service innovation increases & Shepherd \\
& & 3 Product/service quality increases & $(2003)$ \\
\hline
\end{tabular}

\subsection{Population, Sample and Unit Analysis}

The population is known from e-commerce registered in the Indonesian E-Commerce Association (idEa). IdEa is a communication forum between Indonesian E-Commerce industry players. The e-commerce category in IDEa consists of classified ads, infrastructure, logistics, marketplace, online retail, and travel. While e-commerce researched in this study only focused on the category of marketplace and travel as many as 106 e-commerce. Because, the majority of e-commerce registered in the idea are in the category of marketplace and travel, while other ecommerce minorities are in another category.

The research sample was taken from the e-commerce population registered in the Indonesian E-Commerce Association (IDEa). The sample size of this study are 61 samples of 106 population. The number of representative samples for the PLS SEM method according to [38] are 30 to 100 , because PLS SEM is based on variance so the number of samples used does not need to be large. The unit of analysis that will be observed is growth-oriented 
ecommerce. The sampling technique uses nonprobability sampling techniques where sampling is intended for members of the population not to get the same opportunity to be selected as a sample [39]. Because the e-commerce population studied in this study only focused on marketplace and travel. The researcher used purposive sampling to be used because only respondents were members of the Indonesian E-Commerce Association (IDEa) and were categorized as marketplace and travel.

\subsection{Data Analysis Method}

SEM is a multivariate statistical technique that is popular in business research. SEM explains the relationship between several variables [40]. SEM can simply estimate a large set of regression equations but is interdependent at the same time by identifying the similarity of the structural model [40].

There are 2 approaches in SEM, namely SEM with covariance (covariance based SEM, CBSEM) and SEM with a variant approach (partial least square path modeling -PLS-SEM). This study uses partial least squares (PLS). Because it analysis performed to test the research model using SmartPLS software. This study used PLS analysis because of the following considerations:

1) PLS analysis is component-based approach and doesn't have strict requirements for sample size [41];

2) PLS is also a powerful analytical method because it is not based on many assumptions and it is possible to analyze from various indicators of latent variables;

3) PLS analysis can evaluate theoretical structural models and measurement models simultaneously [42];

4) PLS can accommodate the indicator variable either indicator is formative or reflective.

Variable reliability is analyzed using alpha and Cronbach composite reliability. Alpha Cronbach at least 0.5 or higher to form composite measurement [43]. AVE presents the number of variance in the measurement item recorded by the latent construct, and the AVE value limit must be a minimum of 0.5 [44].

This study seeks to investigate the implement of strategic entrepreneurship to e-commerce in Indonesia. This study will be conduct from the background of the problems, theoretical background, research model and hypotheses then the operationalization of the variables. The concept and operationalization developed in this paper is ongoing to be finished for further empirical research.

\section{Method}

Based on the questionnaire distributed the respondents' data are obtained as follows:

Table 5. E-commerce Profile

\begin{tabular}{|c|l|l|c|c|}
\hline No & \multicolumn{2}{|c|}{ Category } & Total & Persentase \\
\hline 1 & Location & $\begin{array}{l}\text { DKI } \\
\text { Jakarta }\end{array}$ & 56 & $91.5 \%$ \\
\cline { 3 - 5 } & & Jawa Barat & 2 & $3 \%$ \\
\cline { 3 - 5 } & & Banten & 3 & $4.9 \%$ \\
\hline
\end{tabular}




\begin{tabular}{|c|l|l|c|c|}
\hline 2 & Spesific & B2B & 1 & $1.6 \%$ \\
\cline { 4 - 5 } & & B2C & 0 & $88.5 \%$ \\
\hline & C2C & 6 & $9.8 \%$ \\
\hline 3 & Age of ecommerce & $1-2$ yo & 0 & $6.5 \%$ \\
\hline & $2-3$ yo & 0 & $26.2 \%$ \\
\hline & $3-4$ yo & 0 & $8.2 \%$ \\
\hline & $4-5$ yo & 0 & $21.3 \%$ \\
\hline & $\geq 5$ yo & 0 & $36 \%$ \\
\hline
\end{tabular}

The location of e-commerce is centered only in Jakarta but has a broad business reach covering Indonesia and even globally. The centralization of locations in Jakarta is due to the availability of adequate infrastructure, competent human resources, diverse modes of transportation, a business environment that supports and closeness to the market.

Furthermore, the dominant market for e-commerce developing in Indonesia is B2C. B2C is seen to be the most suitable for customer needs because services are carried out directly to customers so that there is cost savings, making it easier to break the sales chain (intermediary). From the business side, the need for working capital will be lower compared to conventional business cases so that prices can be reduced to cheaper customers, direct access to global markets, and business activities that live 24 hours / 7 days.

For the age of e-commerce, it can be concluded that the business environment in Indonesia can support the sustainability of e-commerce businesses. Although competition tends to be tight, e-commerce can survive in capturing opportunities and maintaining competitive advantage.

Table 6. Respondents' demographics

\begin{tabular}{|c|c|c|c|c|}
\hline No & \multicolumn{2}{|c|}{ Category } & Total & Persentase \\
\hline \multirow[t]{2}{*}{1} & \multirow[t]{2}{*}{ Gender } & Female & 21 & $47.5 \%$ \\
\hline & & Male & 32 & $52.5 \%$ \\
\hline \multirow[t]{3}{*}{2} & \multirow[t]{3}{*}{ Age of respondent } & $21-30$ уо & 50 & $81.9 \%$ \\
\hline & & $31-40$ уо & 9 & $18.1 \%$ \\
\hline & & $\geq 40$ yo & 0 & $0 \%$ \\
\hline \multirow[t]{2}{*}{3} & \multirow[t]{2}{*}{ Education } & D1/D2/D3 & 0 & $0 \%$ \\
\hline & & S1 & 52 & $85.3 \%$ \\
\hline
\end{tabular}




\begin{tabular}{|l|l|c|c|c|}
\cline { 3 - 4 } & $\mathrm{S} 2$ & 9 & $14.7 \%$ \\
\cline { 3 - 4 } & $\mathrm{S} 3$ & 0 & $0 \%$ \\
\hline
\end{tabular}

Based on table 3.2 if sorted from the majority, there are 32 male respondents $(52.5 \%)$ and $29(47.5 \%)$ women. So, it can be concluded that the results of this study do not reflect gender differences. Because the difference in number between the two sexes is small. Another conclusion is that there is an even distribution in terms of gender in e-commerce.

The age of the respondents if sorted from the majority has the following details: 50 people aged 21-30 years (81.9\%), 11 people aged $31-40$ years $(18.1 \%)$, and no respondents aged > 40. Based on these data it can be concluded that most respondents ranged in age from 21-30 years, namely productive age where they are responsive or sensitive to opportunities and know how to pursue it, have creative ideas, have a good understanding of technology and can work together on teams and individuals. This can support the competitive landscape of the ecommerce environment.

Respondent education if sorted from the majority has the following details: 52 people with S1 education (85.3\%), 9 people with S2 education (14.7\%), no respondents with education from D1 / D2 / D3 or S3. So that it can be concluded that most respondents have a good educational background (S1 and S2), so they are considered competent in answering this research questionnaire. The results of the study are expected to approach reasonableness because they present the answers of respondents who have good competencies.

Table 7 Hypothesis Test Results

\begin{tabular}{|l|l|l|l|l|}
\hline \multicolumn{2}{|c|}{ Hypothesis } & t-value & Significant & Conclusion \\
\hline H1 & $\begin{array}{l}\text { Strategic entrepreneurship has a positive effect } \\
\text { on dynamic capabilities }\end{array}$ & 11.226 & Significant & Accepted \\
\hline H2 & $\begin{array}{l}\text { Strategic entrepreneurship has a positive effect } \\
\text { on innovation }\end{array}$ & 3.345 & Significant & Accepted \\
\hline H3 & $\begin{array}{l}\text { Dynamic capabilities have a positive effect on } \\
\text { innovation }\end{array}$ & 1.317 & $\begin{array}{l}\text { Not } \\
\text { Significant }\end{array}$ & Rejected \\
\hline H4 & $\begin{array}{l}\text { Dynamic capabilities have a positive effect on } \\
\text { performance }\end{array}$ & 5.268 & Significant & Accepted \\
\hline
\end{tabular}




\begin{tabular}{|l|l|l|l|c|}
\hline H5 & $\begin{array}{l}\text { Innovation has a positive effect on } \\
\text { performance }\end{array}$ & 2.136 & Significant & Accepted \\
\hline
\end{tabular}

The results of the study show that the majority of $\mathrm{B} 2 \mathrm{C}$ e-commerce has implemented strategic entrepreneurship in business operations which also affects dynamic capabilities and innovations to improve company performance. In the discussion of the results analysis will be explained through three paths, namely the dynamic capability path and the innovation path to performance. And the last path that will discuss the relationship of dynamic capabilities to innovation.

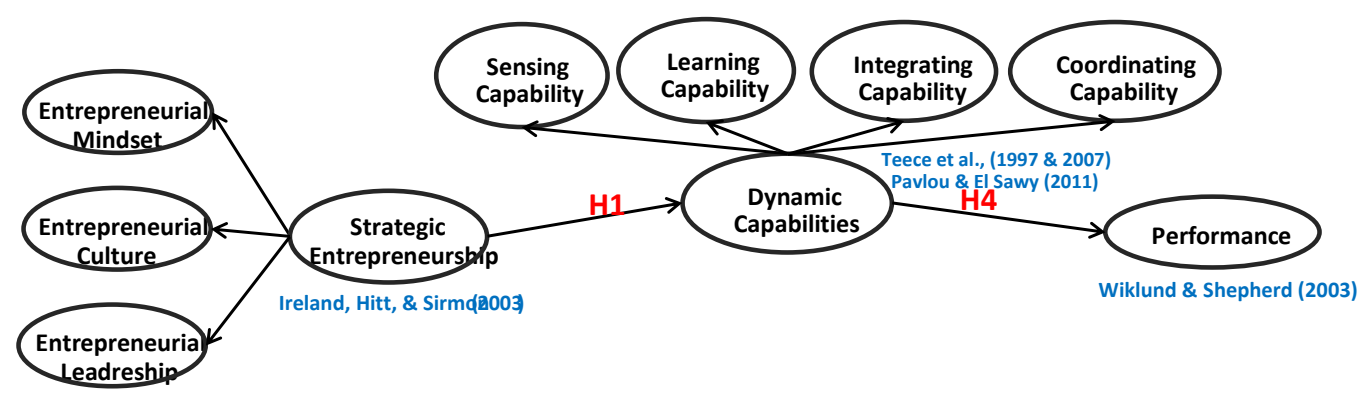

Fig. 3. First Path

The first path to be discussed is the influence of strategic entrepreneurship in relation to dynamic capabilities to the performance of B2C e-commerce. In B2C e-commerce, strategic entrepreneurship has a positive influence on dynamic capabilities. Most of the e-commerce B2C often scan conditions outside, seek information about technological developments which then become new knowledge material for companies that can be managed through Sharing Knowledge. This new information, knowledge and capability has an influence on the entrepreneurial mindset of the company. So that $\mathrm{B} 2 \mathrm{C}$ e-commerce is encouraged to continue to look for opportunities and take risks.

Furthermore, the results of information and knowledge processes obtained from outside are transformed into new capabilities and incorporated into the company's current activities. This process will affect the culture of entrepreneurship. Companies will be better at listening to opinions or capturing information, more competent in taking measured risks. The existence of fault tolerance is then used as learning material. The company can also create open communication, so that proactive innovations will be created for new products or processes. The company will encourage each employee to cooperate with each other. Thus, the process of seeking knowledge, transforming knowledge into new capabilities and incorporating into company activities, will encourage the formation of an entrepreneurial culture on $\mathrm{B} 2 \mathrm{C}$ ecommerce.

Then the search for information and knowledge will instill that knowledge into new capabilities that will create leadership patterns oriented to the search for opportunities and competitive advantage. From this process, leaders in $\mathrm{B} 2 \mathrm{C}$ e-commerce can determine organizational systems, spread vision, be flexible, be able to see opportunities in the future, build good guesses and test them efficiently in a complex and changing business environment. B2C ecommerce leaders are also able to communicate, influence organizational members, 
understand others and develop knowledge. So that it can be concluded that strategic entrepreneurship possessed by B2C e-commerce can be used to enhance dynamic capabilities.

In relation to performance, dynamic capabilities have a positive influence. The ability of B2C e-commerce to maintain, modify and reconfigure its current capabilities into new capabilities influences improving e-commerce performance. Dynamic capability is needed by e-commerce to create new capabilities so that new resource bases can be created. E-commerce researched states that they can develop and combine resources (HR and technology) to be better and superior, besides using strategies and capabilities in accordance with market conditions. So, they can experience increased sales and profits. Dynamic capability is also able to improve the quality of products / services and get customer satisfaction. But it is necessary to have routine activities to trigger the development of innovation in products / services.

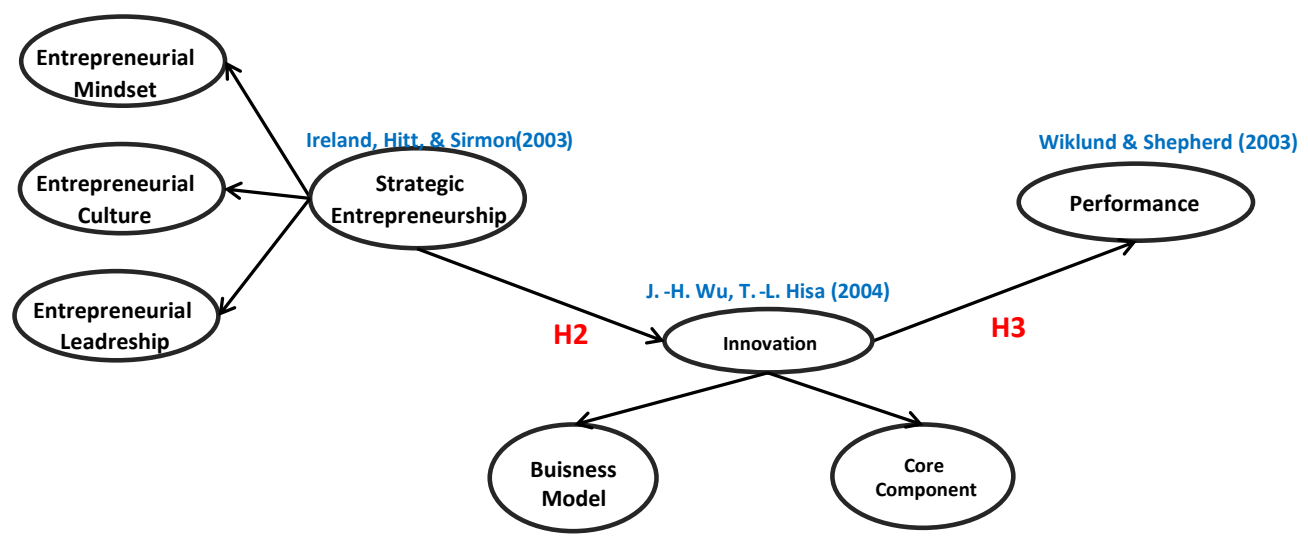

Fig. 4. Second Path

The second path to be discussed is the influence of strategic entrepreneurship in relation to innovation on the performance of $\mathrm{B} 2 \mathrm{C}$ e-commerce. In $\mathrm{B} 2 \mathrm{C}$ e-commerce pay attention to opportunity search behavior and the creation of competitive advantages over time, even in difficult financial situations. Although in e-commerce, entrepreneurs place more emphasis on opportunity search behavior while management places more emphasis on creating competitive advantage behaviors. This shows that the focus between entrepreneurs and management in ecommerce must be understood. The balance between the two behaviors in e-commerce can be achieved by using innovation, especially parallel business models in which opportunity seeking behavior and the creation of competitive advantage go together and complement each other over time. At present, parallel business models have been widely applied by B2C ecommerce. This business model is also supported by core components as input in the business model that includes application platforms and mobile devices and provides content and services. The purpose of supporting the core component in the business model is to maintain the security and trust of customers in making transactions. Security and trust are important in reducing consumer concerns in online transactions. Security and trust will trigger the creation of loyalty to customers. With customer loyalty, e-commerce has reached a target which is also followed by an increase in technology infrastructure.

In relation to performance, innovation helps e-commerce in designing to create product / service specifications and applied business models combined with technology infrastructure. 
Technology infrastructure facilitates e-commerce in creating business models to create value propositions for customers such as mobility, localization (removing location or geographic boundary constraints between sellers and buyers), and convenience (providing value-for-time to customers with ease of transaction so efficiency occurs time and energy in shopping). Technology infrastructure in e-commerce also makes it easy to collect user transaction information in various locations in real-time (that is, companies can track customer movements when shopping and make customer transaction information a new opportunity). In terms of information, innovation in ecommerce can eliminate information asymmetry between customers and sellers and thus create an almost 'friction-free' market where buyers and sellers are connected directly without having to face to face. The e-commerce business model allows managers to capture opportunities by segmenting customers and implementing different strategies based on customer segments. So that they are able to improve their performance in increasing sales and profits, improving product / service quality and customer satisfaction.

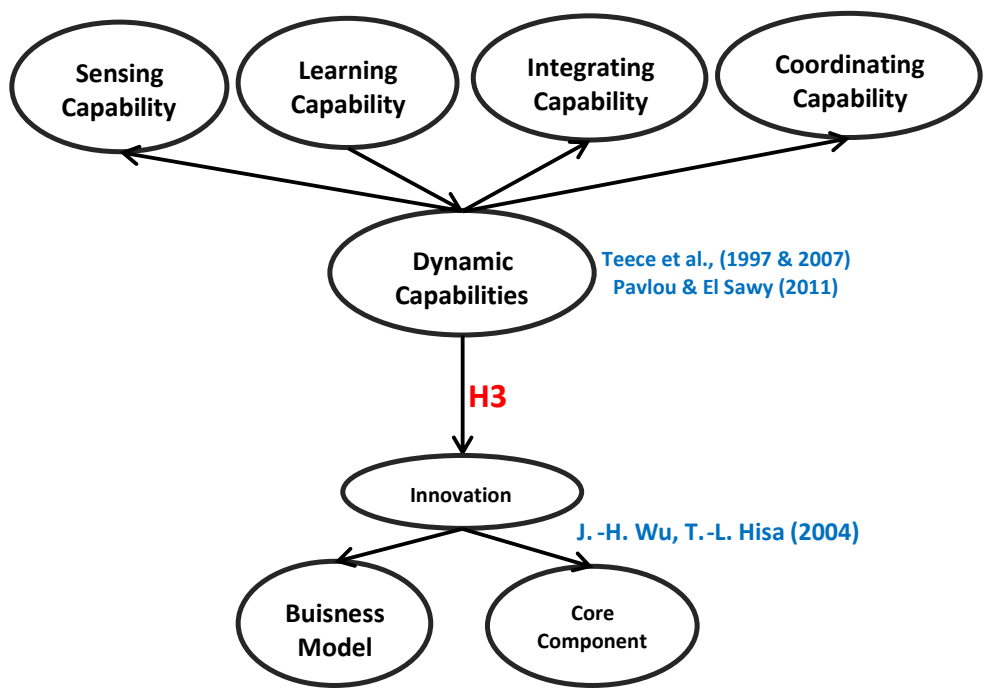

Fig. 5. Third Path

The third path to be discussed is the effect of dynamic capability on innovation. In B2C ecommerce, dynamic capabilities have no significant influence on innovation. The results of the study found that the majority of $\mathrm{B} 2 \mathrm{C}$ e-commerce focused more on search behavior opportunities that were carried out continuously on the market. This B2C e-commerce activity will be dangerous for the company because it can be trapped in an endless opportunity search routine with inefficient use of resources. Given the limited resources of B2C e-commerce. This opinion is reinforced by the theory of Ireland \& Webb (2007) who say that just looking for opportunities is not enough. Companies that are too focused on finding opportunities tend to get caught up in the ongoing search cycle and cycle of change (Raisch \& Birkinshaw, 2008). This situation can make companies use their resources ineffectively because they are trapped in continuous search and change (March, 1991). In conjunction with innovation, it is better for e-commerce to directly focus on innovation without forming dynamic capabilities first. 
In addition, opportunity identification and exploitation opportunities can be done quite well by decision makers, but they only create a temporary competitive advantage rather than sustainable competitive advantage [11]. This happens because decision makers in $\mathrm{B} 2 \mathrm{C}$ ecommerce cannot manage their resources strategically, so that competitive advantages that have been developed are difficult to change into sustainable competitive advantage [6]. This is one problem that must be considered by decision makers or founders in $\mathrm{B} 2 \mathrm{C}$ e-commerce.

E-commerce is difficult to develop dynamic capabilities because the development of dynamic capabilities requires time and funds that are not small. Investment in dynamic capabilities lies in knowledge-based human resources. Human resources have valuable, rare, difficult to imitate and irreplaceable characteristics (VRIN) so that it is an important resource in encouraging the creation of sustainable competitive advantage [11]. Development of dynamic capabilities always requires investment in development and commercialization [33].

So, obtaining funds, recruiting and training employees to run operations [45] are examples of developing dynamic capabilities that support the business models needed by ecommerce [46]. It is true that funding and employees are a much-needed resource especially for $\mathrm{B} 2 \mathrm{C}$ e-commerce.

\section{Conclusion}

This study aims to examine empirically the influence of strategic entrepreneurship in relation to dynamic capabilities and innovation in achieving performance in the e-commerce sector. The entrepreneurial theory of strategy is an integration of opportunity-seeking behavior and advantage-seeking behavior. Both behaviors work simultaneously and not separately. The combination of these two behaviors will give maximum results on e-commerce performance if there is dynamic capability and innovation.

\section{References}

[1] S. Post, Indonesia's eCommerce Landscape 2014. Singapore: Singapore: Post Limited.

[2] N. Freischlad, "Google: Indonesia will dominate Southeast Asian ecommerce.".

[3] V. Sinha, "Where is Indonesian e-commerce headed?" .

[4] M. Wade, Hulland, and John, "Review: The Resource-Based View and Information Systems Research: Review, Extension and Suggestions for Future Research," MIS Q., vol. 28 , p. 1 .

[5] A. Rauch, J. Wiklund, G. T. Lumpkin, and M. Frese, "No Title," Entrep. Theory Pract., vol. 33, no. 3, pp. 761-787.

[6] R. D. Ireland, M. A. Hitt, S. M. Camp, and D. L. Sexton, "Integrating Entrepreneurship and Strategic Management Actions to Create Firm Wealth," Acad. Manag. Exec., vol. 15, no. 1, pp. 49-63.

[7] G. Hamel and C. K. Prahalad, "Strategic Intent." .

[8] J. G. March, "Exploration and Exploitation in Organizational Learning," Organ. Sci., vol. 2, no. 1, pp. 71-87.

[9] V. Ambrosini, Bowman, and C., "What Are Dynamic Capabilities and Are They a Useful Construct in Strategic," Manag. Int. J. Manag. Rev., vol. 11, pp. 29-49.

[10] N. Foss, Klein, and P. G, "Entrepreneurship and the economic theory of the firm: Any gains from trade?," in Handbook of Entrepreneurship Research: Disciplinary Perspectives, S. A. Alvarez and R. A. and O. Sorenson, Eds. New York, NY: Springer, pp. 55-80.

[11] R. D. Ireland, M. A. Hitt, and D. G. Sirmon, “A Model of Strategic Entrepreneurship: The Construct and its Dimensions," J. Manage., vol. 29, no. 6, pp. 963-989. 
[12] L. Kyrgidou and M. Hughes, "Strategic Entrepreneurship: Origins, Core Elements and," Res. Dir. Eur. Bus. Rev., vol. 22, no. 1, pp. 43-63.

[13] S. A. Zahra, "Entrepreneurship and disciplinary research: Return to the fountainhead," in Handbook of Entrepreneurship, S. Alvarez, R. Agarwal, and and O. Sorenson, Eds. Boston, MA: Kluwer, pp. 253-268.

[14] K. M. Eisenhardt and J. A.Martin, "Dynamic Capabilities: What are They? Strategic management," Journal, vol. 21, pp. 1105-1121.

[15] P. A. Pavlou, E. Sawy, and O. A, "Understanding the Elusive Black Box of Dynamic Capabilities,” Decis. Sci., vol. 42, no. 1.

[16] D. F. Kuratko, R. D. Ireland, J. G. Covin, and J. S. Hornsby, "A Model of Middle-level Managers'," Entrep. Behav. Entrep. Theory Pract., vol. 29, no. 6, pp. 699-716.

[17] D. F. Kuratko and D. B. Audretsch, "Strategic Entrepreneurship: Exploring Different Perspectives of an Emerging Concept," Entrep. Theory Pract., vol. 33, no. 1, pp. 1-17.

[18] J.-H. Wu and T.-L. Hisa, Analysis of E-Commerce Innovation and Impact: a Hypercube Model. Science Direct.

[19] D. G. Sirmon, M. A. Hitt, and R. D. Ireland, "Managing Firm Resources in Dynamic Environments to Create Value: Looking Inside the Black Box," Acad. Manag. Rev., vol. 2007, no. 32, pp. 273-292.

[20] R. D. Ireland, R. E. Hoskisson, and M. A. Hitt, The Management of Strategy: Concepts and Cases. Mason, Ohio: SouthWestern Cengage learning.

[21] D. J. Teece, "Technological Innovation and The Theory of The Firm: The Role Of Enterprise-Level Knowledge, Complementarities," California, USA.

[22] G. Hamel, Leading the Revolution. Boston, Massachusetts: Harvard Business School Press.

[23] A. Fontana, "Innovate We Can! How to Create Value through Innovation in Your Organization and Society. Grasindo.”.

[24] D. J. Teece., G. Pisano, and A. Shuen, "Dynamic Capabilities and Strategic," Manag. Strateg. Manag. J., vol. 18, no. 7, pp. 509-533.

[25] J. B. Kamm, "An integrative approach to managing innovation." Lexington Books, Lexington, Mass.

[26] E. Huizingh and M. Brand, "Stepwise innovation adoption: A neglected concept in innovation research," Int. J. Technol. Manag., vol. 45, pp. 267-281.

[27] J. A. Schumpeter, "Comments on a plan for the study of entrepreneurship," R. S. A, Ed. Princeton, NJ: Princeton University Press, pp. 406-428.

[28] M. Porter and C. Ketels, "UK Competitiveness: Moving to the Next Stage.".

[29] E. R. Wagner, "Eric N. Hansen," Manag. Decis., vol. 43, no. 6, pp. 837-850.

[30] J. Kilbourne, Can't buy my love: How advertising changes the way we think and feel. New York: Simon \& Schuster.

[31] H. Li, J. Ma, and W. Duan, "The Standardization of Online Public Relations Is Imperative," in Management and Service Science (MASS), 2010 International Conference on, pp. 1-4.

[32] A. M. McGahan and M. E. Porter, "The Emergence and Sustainability of Abnormal Profits," Strateg. Organ., vol. 1, no. 1, pp. 79-108.

[33] D. Teece, "Explicating Dynamic Capabilities: The Nature and Microfoundations of (Sustainable) Enterprise Performance.”.

[34] M. Eisenhardt, "Top management teams and the performance of entrepreneurial firms," Small Bus. Econ., vol. 40, no. 4.

[35] A. Afuah and N. Bahram, "The hypercube of innovation," Res. Policy, vol. 24, pp. 51- 
76.

[36] A. D. Neely, Business Performance Measurement: Unifying Theories and Integrating Practice. Cambridge: Cambridge University Press.

[37] J. Wiklund and D. Shepherd, "Knowledge-based Resources, Entrepreneurial Orientation, and the Performance of Small and Medium - sized Businesses," Strateg. Manag. J., vol. 24, no. 13, pp. 1307-1314.

[38] J. Hair, H. F., G. T. M., C. Ringle, dan S. M., and Marko, A primer on partial least squares structural equation modelling (PLS-SEM). SAGE Publications, Inc.

[39] U. Sekaran and R. Bougie, Research Methods for Business: A Skill-Building Approach. John Wiley \& Sons: United Kingdom.

[40] J. Hair, B. F., B. W.C., A. B.J., dan T. R.E, and R.L., Multivariate data analysis. Sixth Edition. Pearsons Educations. River, New Jersey: Inc. Upper Saddle.

[41] J. B. Lohmöller, Latent variable path modeling with partial least squares. Heidelberg: Physica-Verlag.

[42] W. Chin, M. W., B.L., and P. R. Newsted, "A Partial Least Squares Latent Variable Modeling Approach for Measuring Interaction Effects: Results from a Monte Carlo Simulation Study and an Electronic-Mail Emotion/Adoption Study," Inf. Syst. Res., vol. 14 , no. 2 , pp. $189-217$.

[43] C. Fornell and F. L. Bookstein, "Two Structural Equation Models: LISREL and PLS Applied to Consumer Exit-voice Theory," J. Mark. Res., vol. 19, no. 4, p. 440.

[44] C. Fornell and D. F. Larcker, "Structural equation models with unobservable variables and measurement error: algebra and statistics," J. Mark. Res., vol. 18, no. 3, pp. 382 388.

[45] J. F. Hair, C. M. Ringle, and M. Sarstedt, "PLS-SEM: Indeed a Silver Bullet," J. Mark. Theory Pract., vol. 19, no. 2, pp. 139-152.

[46] R. D. Ireland and J. W. Webb, "Strategic Entrepreneurship: Creating Competitive Advantage Through Streams of Innovation,” Bus. Horiz., vol. 50, pp. 49-59. 